\title{
術後性上䪽囊胞の症状発現に関連する因子の臨床的検討
}

\author{
和田卓也・中村誠 司・竹之下康治 \\ 浜崎 修·二宮史浩・篠原正徳 \\ 荒木和之*·白砂兼光
}

\section{Clinical study of factors associated with the expression of symptoms in postoperative maxillary cyst}

\author{
Takuya Wada - Seiji Nakamura $\cdot$ Yasuharu Takenoshita \\ Osamu Hamasaki $\cdot$ Tomohiro Ninomiya $\cdot$ Masanori Shinohara \\ Kazuyuki Araki*'Kanemitsu ShIRASUna
}

\begin{abstract}
In 169 patients with postoperative maxillary cysts who were operated on at our clinic, we examined the clinical course of disease, clinical symptoms, characteristics of the cysts, location and size of the cysts, location and size of the bone defects, and positional relationship between the cysts and teeth. Furthermore, factors associated with the expression and the type of symptoms were also examined, and the following results were obtained.

1 ) Characteristics of cysts: Multilocular cysts were associated with more frequent and severer symptoms than unilocular cysts.

2 ) Location and size of cysts: Cysts in a lower position were frequently associated with symptoms, especially intraoral symptoms. Cysts in a higher position were associated mainly with buccal symptoms. Cyst size was not significantly associated with the occurrence of symptoms.

3 ) Location and size of bone defects: Cysts with bone defects in the anterior part of the maxillary sinus were frequently associated with symptoms, especially buccal symptoms. Furthermore, large bone defects were more frequently associated with symptoms.

4 ) Positional relationship between cysts and teeth: Cysts with root chip (s) in their cavities were frequently associated with symptoms, especially intraoral symptoms.

Examination of factors associated with the occurrence and type of symptoms will help to predict the outcome of postoperative maxillary cysts and help to determine whether or not an operation is indicated for symptom-free cysts.
\end{abstract}

Key words: postoperative maxillary cyst (術後性上顎克胞), axial computed tomography（軸位 $\mathrm{CT}$ )

九州大学歯学部口腔外科学第二講座

(主任 : 白砂兼光教授)

*九州大学歯学部歯科放射線学講座

(主任 : 神田重信教授)

Second Department of Oral and Maxillofacial

Surgery, Faculty of Dentistry, Kyushu University
(Chief: Prof. Kanemitsu Shirasuna)

* Oral and Maxillofacial Radiology, Faculty of Dentistry, Kyushu University (Chief: Prof. Shigenobu Kanda)

受付日：平成 8 年 4 月 8 日 
緒

言

術後性上顎襄胞は, 上顎洞炎根治術後の晚発性疾患 として1927年に久保 ${ }^{1)}$ に命名されたが, 口腔外科領域 においても比較的頻度の高い疾患であり，今日までに 多数の報告がみられる ${ }^{1 \sim 25)}$. 近年では, 画像診断, 特 にCTによる検討によって, 囊胞の形状, 大きさ, 位置, 骨欠損の大きさ, 位置などが術前にほぼ把握できるよ うになった。しかし同時に，両側の根治術の既往のあ る症例では, 症状のない側にも襄胞が発見される場合 があり，その予後を推定したり治療方針を決定する際 に苦慮することも少なくない.

今回われわれは, 当科に掠いて術後性上顎襄胞の手 術を施行した症例について臨床的に検討し, 症状の発 現や症状の種類に関連すると思われる種々の因子につ いて検討したので報告する。

\section{対象および方法}

検索対象は, 1985年から1994年までの10年間に当科 で手術を施行した169症例で, 性別は男性106例，女性 63例である.このうち, 再発症例が21例含まれていた。 片側のみの手術を施行した症例が148例，両側ともに 手術を施行した症例が21例で，このうち両側同時に手 術を施行した症例が 9 例含まれていた。手術側は計 190側で, 右側が98側, 左側が92側であった.

術前治療としては，必要に応じて120例で消炎のた めに抗生剂や消炎剂を投与し, 症状が強い場合はさら に穿刺吸引 (38例) や切開排膿処置 (33例) を施した。 手術方法は, 基本的には虽胞壁を全摘し, 多胞性のも のは隔壁を除去して単胞化し，下鼻道へ対孔を形成す る方針にしており，58例 $(30.4 \%)$ で囊胞全摘および
対孔形成を行った.しかし，囊胞壁に骨の裏打ちがな い場合や，生活歯の根尖部を損傷させるおそれがある 場合はその部の囊胞壁を保存しており，109例（57.0 \%) で囊胞部分摘出および対孔形成を行った。また， 囊胞壁が菲薄でかつ単胞性の場合には大歯窖に準備孔 を開けて下鼻道への開空のみを行う場合があり，開空 部を形成後は準備孔部を閉鎖した. そのような下鼻道 への開空のみの症例が24例（12.6\%）あった.

検索にあたっては, 性別, 年齢, 来院までの経過, 症 状, 治療, 術後の経過などは診療録, 手術記録に基つ いて, 霊胞の位置や形状, 囊胞と歯牙との位置的関係, 骨欠損の大きさや位置などは手術記録, 単純 X 線写真, 軸位 CT 像に基づいて調査した。

\section{結果}

\section{1. 術後性上顎高胞の手術までの経過について}

上顎洞炎根治術時の年齢は 10 歳から 56 歳までで, 10 歳台が最も多く, 平均年齢は 20.0 歳であった (図 1 -A). 本疾患の初発時年齢は23歳から77歳までで，40歳台が 最も多く, 平均年齢は 44.3 歳であった (図 1-B). 上顎 洞炎根治術から本疾患の初発までの経過年数は 5 年か ら57年までで, 平均25.5年であった（図 2 -A).

21例の再発症例においては, 前回の手術から再発ま での経過年数は 1 か月から 37 年までで, 平均 10.4 年で あり, 上顎洞炎根治術から本疾患の初発までの経過年 数に比べて明らかに短かった（図 $2-B$ ).

\section{2 . 症状について}

術前の患者の主訴および自・他覚的症状としては, いずれも腫脹や疼痛といった㚘部症状を呈した症例が 多かった（表 1 ). 口腔内症状では歯肉の腫脹, 疼痛, 歯痛が多くみられた. また, 頻度は少ないものの鼻閉

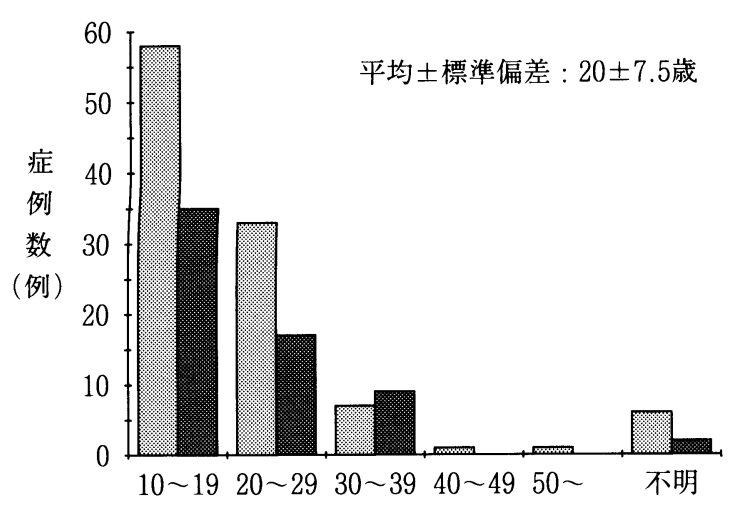

年齢（歳）

A）上顎洞炎根治術時の年齢

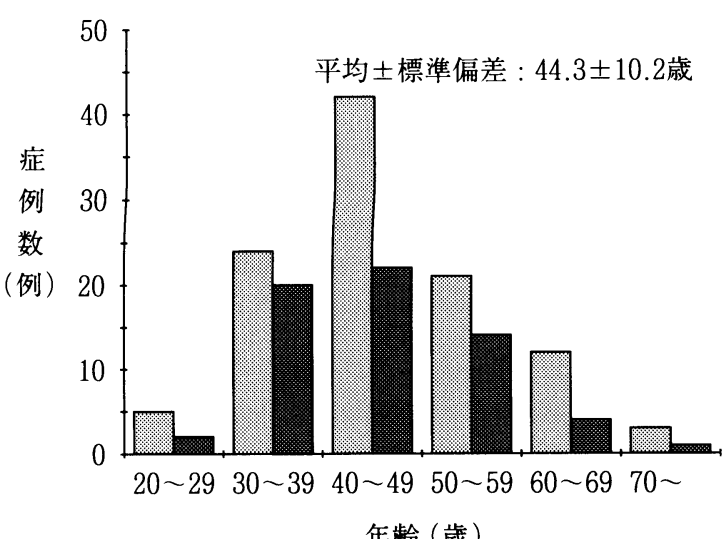

B）術後性上顎襄胞の初発時の年齢 


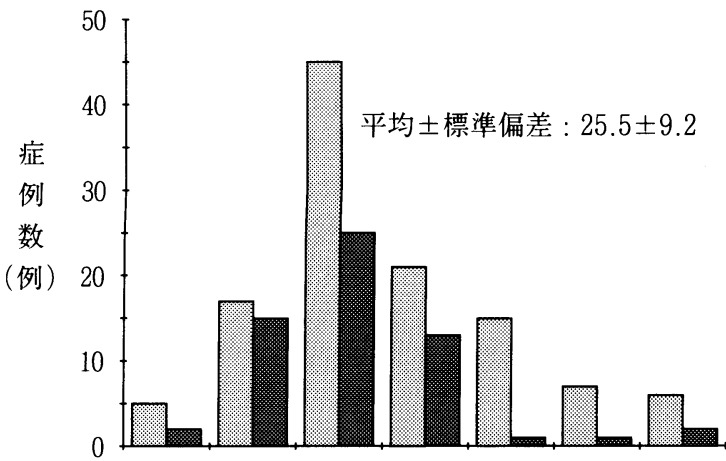

$00 \sim 09$ 10 19 20 29 30 39 40 49 50 59 不明

経過年数（年)

A）上顎洞炎根治術から初発までの経過年数

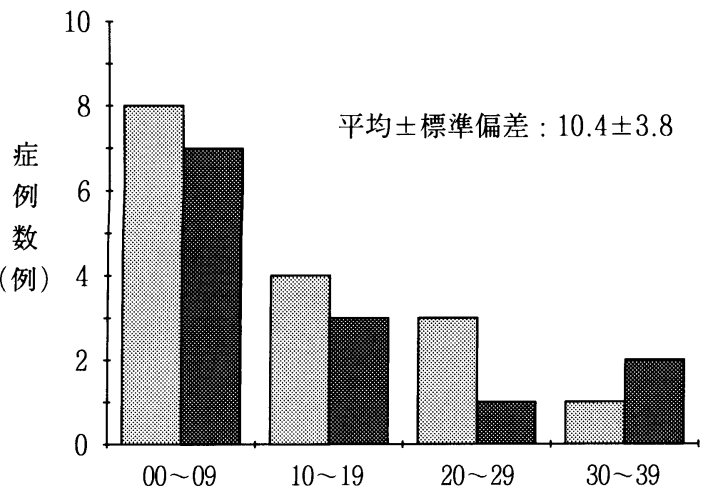

経過年数 (年)

B）再発までの経過年数

図 2 上顎洞炎根治術から初発および再発までの経過年数.（四男性 四性）

表 1 主訴および自・他覚的症状

\begin{tabular}{|c|c|c|c|}
\hline \multirow[b]{2}{*}{ 部 位 } & \multirow[b]{2}{*}{ 症 状 } & \multicolumn{2}{|c|}{ 症 例 数 (\%) } \\
\hline & & 主 訴 & 自 - 他覚的症状 \\
\hline \multirow[t]{3}{*}{ 煩 部 } & 脹 & $61(33.5)$ & $80(44.0)$ \\
\hline & 痛 & $49(26.9)$ & $97(53.3)$ \\
\hline & 違 和 感 & $24(13.2)$ & $32(17.6)$ \\
\hline \multirow[t]{4}{*}{ 口腔内 } & 歯肉腫脹 & $24(13.2)$ & $50(27.5)$ \\
\hline & 歯肉疼痛 & $22(12.1)$ & $46(25.3)$ \\
\hline & 歯 痛 & $13(7.1)$ & $33(18.1)$ \\
\hline & 排 & $15(8.2)$ & $36(19.8)$ \\
\hline \multirow[t]{2}{*}{ 鼻 } & 鼻 閉 感 & $1(0.5)$ & $22(12.1)$ \\
\hline & 鼻 & $0(0.0)$ & $5(2.7)$ \\
\hline 頭 & 痛 & $0(0.0)$ & $11(6.0)$ \\
\hline 眼 & 眼 症 状 & $1(0.5)$ & $5(2.7)$ \\
\hline 精査等 & & $6(3.3)$ & $6(3.3)$ \\
\hline
\end{tabular}

表 2 豊胞の形状

\begin{tabular}{|c|c|c|c|}
\hline \multicolumn{2}{|c|}{ 囊胞数 } & 症例数 & (\%) \\
\hline \multicolumn{2}{|l|}{ 単胞性 } & 101 & $(70.6)$ \\
\hline \multirow[t]{4}{*}{ 多胞性 } & 2 & 27 & $(19.0)$ \\
\hline & 3 & 11 & $(7.7)$ \\
\hline & 4 & 1 & $(0.7)$ \\
\hline & 5 以上 & 3 & $(2.1)$ \\
\hline \multicolumn{2}{|c|}{ 計 } & 143 & $(100.0)$ \\
\hline
\end{tabular}

囊胞断面積平均値 : $4.29 \pm 4.37 \mathrm{~cm}^{2}$
表 3 震胞の内容液の色

\begin{tabular}{|c|c|c|}
\hline 内容液の色 & 襄胞数 & $(\%)$ \\
\hline 白～黄色 & 52 & $(27.4)$ \\
\hline 茶～黒色 & 31 & $(16.3)$ \\
\hline 緑 & 8 & $(4.1)$ \\
\hline 不明 & 99 & $(52.1)$ \\
\hline 計 & 190 & $(100.0)$ \\
\hline
\end{tabular}

感などの鼻症状, 頭痛, 流涙, 眼球突出などの眼症状 もみられた。

\section{3. 震胞の形状について}

169例中143例においては術前にフランクフルト平面 を基準にした軸位の CT 撮影を行っており，CTおよ び術中所見の両方で確認したところ, 単胞性のものが 全体の70\%をしめていた（表 2 ).

囊胞内容液の色は白色から黄色のもの, 茶色から黒 色のもの, 緑色のものの 3 種類に大きく分けると, 白色 から黄色のものが $27.2 \%$ と最も多くみられた（表 3 ）. 内容液の細菌検査を75例で行ったところ, 検出された 菌種ごとにまとめるとグラム陽性球菌が最も多く認め られ，全体の $44.0 \%$ 占めていた（表 4 ）. 菌種と内容 液の色との間には明らかな関連は認められなかった。

\section{4. 亨胞や骨欠損の位置および大きさについて}

囊胞の位置については, 術前に軸位 CT 撮影を行っ た143例について検討した.上下的位置は宮沢ら 2)の 分類を参考にし, 煩骨突起より上方に中心があるもの を上方型，下方にあるものを下方型，両方にまたがる ほど広範なものを全体型と分類した。また，前後的位 置は飯沼ら $\left.{ }^{3}\right)$ の分類を参考に骨欠損の部位を考慮し， 
前壁に骨欠損が認められたものを前方型, 後壁に認め られたものを後方型, 前後両方に広範に骨欠損を認め たものを全体型, 骨欠損の認められなかったものを閉 鎖型とした. 上下的には全体型が66例 $(46.2 \%)$ と最

表 4 内容液から検出された菌種

\begin{tabular}{|c|c|c|}
\hline 種 & 囊胞数 & $(\%)$ \\
\hline グラム陽性球菌 & 33 & $(44.0)$ \\
\hline 通性嫌気性グラム陰性桿菌 & 9 & $(12.0)$ \\
\hline 好気性グラム陰性菌 & 4 & $(5.3)$ \\
\hline 嫌気性グラム陰性桿菌 & 2 & $(2.7)$ \\
\hline 放線菌関連菌 & 2 & $(2.7)$ \\
\hline その他 & 2 & $(2.7)$ \\
\hline 細菌 (-) & 23 & $(30.6)$ \\
\hline 計 & 75 & $(100.0)$ \\
\hline
\end{tabular}

も多く, 下方型と全体型のうちで硬口蓋より下方に及 ぶものが99例（69.2\%）でみられた（図 3 ）。なお，上方 型の 3 例で眼窩底に骨欠損がみられた。前後的には前 方型が78例 $(54.5 \%)$ と過半数を占め, 次に全体型が 46 例 (32.2\%) と多かった (図 4).

豊胞の大きさとして, 軸位 CT 像より囊胞の最大断 面積を求めたところ, 平均 $4.29 \mathrm{~mm}^{2}$ であった，骨欠損 の大きさも，軸位 CT 像より骨欠損の最長幅を計測し たところ，前壁は平均 $9.22 \mathrm{~mm}$ で，後壁は平均 18.89 $\mathrm{mm}$ であった。

5 . 喜胞と歯牙との位置的関係について

術前にX 線的に囊胞と歯根との交通が疑われた症 例は86例で, 全症例の $50.9 \%$ でった。このうち, 術中 に囊胞内への歯根の突出が確認できたのは78例 $(46.2$ $\%$ ）で, 計143本の歯牙が突出していた（表 5 ). 囊胞内 に歯根の突出がみられた歯牙の種類をみてみると，第 一大臼歯, 第二小臼歯がそれぞれ37例 $(25.9 \%), 35$ 例

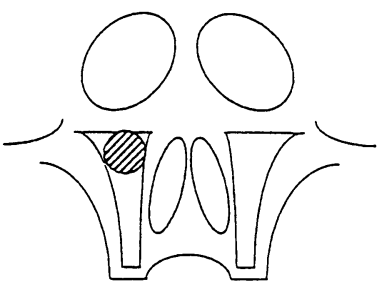

上方型 25例 $/ 143$ 例 $(17.5 \%)$

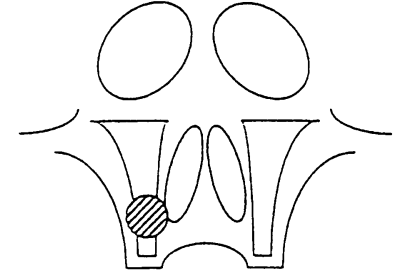

下方型 52 例 $/ 143$ 例 $(36.3 \%)$

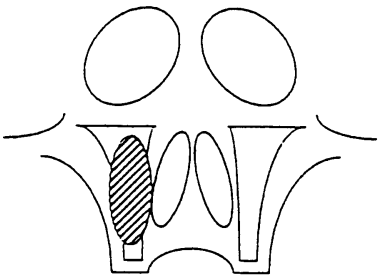

全体型 66 例 $/ 143$ 例 $(46.2 \%)$

下方型と全体型のうち硬口蓋より下方に及ぶものは 99 例 $(69.2 \%)$ にみられた.

図 3 輬胞の位置 (上下的)

後 前

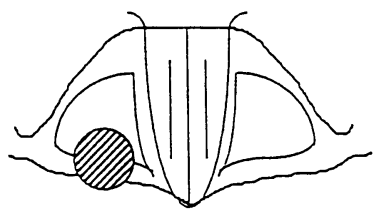

前方型 78 例 $/ 143$ 例 $(54.5 \%)$

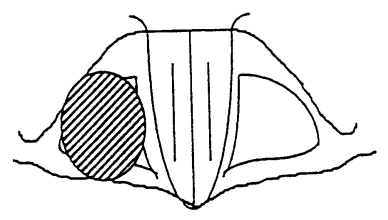

全体型

46例 / 143例 (32.2\%)

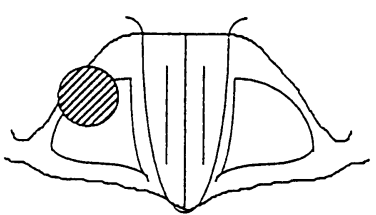

後方型

5 例 $/ 143$ 例 $(3.5 \%)$

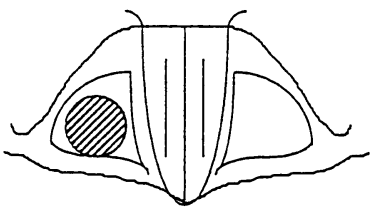

閉鎖型

14例 $/ 143$ 例 $(9.8 \%)$

図 4 聐胞の位置（前後的） 
表 5 囊胞内へ歯根の突出がみられた歯牙

\begin{tabular}{|c|c|c|}
\hline 歯 種 & 本数 & (\%) \\
\hline 中 切 歯 & 2 & $(1.4)$ \\
\hline 側 切 歯 & 3 & $(2.1)$ \\
\hline 犬 & 13 & $(9.0)$ \\
\hline 第一小臼歯 & 26 & $(18.2)$ \\
\hline 第二小臼歯 & 35 & $(24.5)$ \\
\hline 第一大臼歯 & 37 & $(25.9)$ \\
\hline 第二大臼歯 & 20 & $(14.0)$ \\
\hline 第三大臼歯 & 7 & $(4.9)$ \\
\hline 計 & 143 & $(100.0)$ \\
\hline
\end{tabular}

表 6 囊胞の形状と症状の程度との関係

\begin{tabular}{|c|c|c|c|c|}
\hline \multirow[b]{2}{*}{ 囊胞の形状 } & \multicolumn{2}{|c|}{ 症 } & 程 & \\
\hline & ++ & + & - & 計 \\
\hline 単 胞 性 & $19 *$ & 51 & 38 & 108 \\
\hline 多 胞 性 & 9 & 22 & 4 & 35 \\
\hline 計 & 28 & 73 & 42 & 143 \\
\hline
\end{tabular}

*は症例数を示す

++ 群, 十群, 一群の 3 群の間に有意差あり $(\mathrm{P}<0.01)$

+十および+群と一群の 2 群の間に有意差あり

$(\mathrm{P}<0.01)$ (いずれも $\chi^{2}$-検定）

$(24.5 \%)$ と多く, 次いで第一小臼歯，第二大曰歯の順 に多かった。

\section{6 . 症状の発現に関連する因子について}

次にわれわれは, 症状の程度や症状発現の有無と関 連する因子を検討するために, 術前に切開排膿処置が 必要な程症状が強かったものを+十群 (55例), 症状が 軽度で投薬のみで経過をみた症例や，全く投薬をしな かった症例を十群 (127例), 症状はないものの CT に て震胞の存在が認められたものを一群 (42例) と 3 群 に分類した。

上額洞炎根治術時および本疾患発症時の年齢，上顎 洞炎根治術後の経過年数, 性別, 初発か再発かなどの 因子は，3 群間で明らかな差異はみられなかった。以 下, 他の結果を示すが, 一群のほとんどの症例は手術 を施行していないために, 以下の検索は単純 X 線写真 と CT 像に基づいて行った. そのため, CT を施行せず に手術を行った 81 例は除外し, 計143例について検索 した。

\section{1 ）襄胞の形状との関連}

単胞性か多胞性かの違いは, 症状の程度 $(++$ 群, +群, 一群の 3 群間) および症状発現の有無 $(++お$ よび+群と一群の 2 群間) で検定を行い，それぞれ危
表 7 囊胞の位置 (上下的) と症状の程度との関係

\begin{tabular}{|c|c|c|c|c|}
\hline \multirow[b]{2}{*}{ 蕁胞の位置 } & \multicolumn{2}{|c|}{ 症 状 0} & \multicolumn{2}{|c|}{ 程 度 } \\
\hline & ++ & + & - & 計 \\
\hline 上 方 型 & $4^{*}$ & 15 & 6 & 25 \\
\hline 下 方 型 & 10 & 21 & 21 & 52 \\
\hline 全 体 型 & 15 & 42 & 9 & 66 \\
\hline 計 & 29 & 78 & 36 & 143 \\
\hline 最下方型** & 21 & 65 & 13 & 99 \\
\hline それ以外 & 8 & 13 & 23 & 44 \\
\hline 計 & 29 & 78 & 36 & 143 \\
\hline
\end{tabular}

* 症例数を示す. ** 軸位 CTにて歯槽骨に及ぶもの

上方型, 下方型の間での比較;

++ 群, 十群, 一群の 3 群の間に有意差なし

十+群および+群, 一群の 3 群の間に有意差なし

上方型, 全体型の間での比較 ;

+十群, 十群, 一群の 3 群の間に有意差なし

十+群および+群, 一群の 3 群の間に有意差なし

下方型, 全体型の間での比較 ;

+十群, 十群, 一群の 3 群の間に有意差なし

+十群および+群, 一群の 3 群の間に有意差なし

最下方型とそれ以外との比較;

++ 群, +群, 一群の 3 群の間に有意差あり $(\mathrm{P}<0.01)$

十+群および+群, 一群の 3 群の間に有意差あり

$(\mathrm{P}<0.01)\left(\right.$ いずれも $\chi^{2}$-検定 $)$

険率 $1 \% ， 5 \%$ 以下で有意な関連が認められ，多胞性 のほうが症状が発現しやすく，かつ症状が強い傾向に あった（表 6 ）。

2 ) 震胞や骨欠損の位置との関連

囊胞の上下的位置と症状の発現との関連については, 上方型, 下方型, 全体型の 3 型の間では症状の程度や 症状発現の有無に有意な差異はみられなかった（表 7 ). しかし，硬口蓋より下方に及ぶものとそれ以外の 型とに分類すると, 硬口蓋より下方に及ぶものでは症 状が発現しやすい傾向にあった。

骨欠損部位を考慮に入れた前後的位置と症状の発現 との関連については, 閉鎖型は他の型と比較すると明 らかに症状の発現頻度が低かった（表 8 ）。つまり，骨 欠損の有無と症状発現の有無との間には危険率 $1 \%$ 以 下で有意な関連が認められ，骨欠損のあるほうが症状 を発現する頻度が高いことが示された．また，後方型 では前方型と全体型と比較すると症状の発現頻度は低 く, 前壁の骨欠損が症状の発現にはより重要であり, 後壁の骨欠損は必ずしも症状の発現には結びつかない ことも示された。

3 ) 裳胞や骨欠損の大きさとの関連

軸位 CT 像より計測した囊胞の最大断面積は症状の 
表 8 震胞の前後的位置と症状の程度との関係

\begin{tabular}{|c|c|c|c|c|}
\hline \multirow[b]{2}{*}{ 囊胞の位置 } & \multicolumn{2}{|c|}{ 症 } & \multicolumn{2}{|c|}{ 程 度 } \\
\hline & ++ & + & - & 計 \\
\hline 前 方 型 & $16^{*}$ & 41 & 21 & 53 \\
\hline 後 方 型 & 0 & 1 & 4 & 30 \\
\hline 全 体 型 & 12 & 30 & 4 & 43 \\
\hline 閉 鎖 型 & 0 & 1 & 13 & 17 \\
\hline 計 & 28 & 73 & 42 & 143 \\
\hline
\end{tabular}

* 症例数を示す

前方型と後方型の間での比較 ;

+十群, +群, 一群の 3 群の間に有意差あり $(\mathrm{P}<0.05)$

+十および+群と一群の 2 群の間に有意差あり

$(\mathrm{P}<0.05)$

前方型と全体型の間, 後方型と閉鎖型の間での比較 ;

++ 群, 十群, 一群の 3 群の間に有意差なし

+十および+群と一群の 2 群の間に有意差なし

前方型と閉鎖型の間, 後方型と全体型の間, 全体型と閉 鎖型の間での比較 ;

++ 群, +群, 一群の 3 群の間に有意差あり $(\mathrm{P}<0.01)$

+十および+群と一群の 2 群の間に有意差あり

$(\mathrm{P}<0.01)$ (いずれも $\chi^{2}$-検定)

表 9 囊胞断面積および前壁の骨欠損の大きさと症 状の程度との関係

\begin{tabular}{|c|c|c|c|}
\hline & 症 & 状 の 程 & 度 \\
\hline & ++ & + & - \\
\hline $\begin{array}{c}\text { 囊胞断面 積 } \\
\left(\mathrm{cm}^{2}\right)\end{array}$ & $4.04 \pm 2.78$ & $5.02 \pm 5.68$ & $3.21 \pm 2.18$ \\
\hline $\begin{array}{c}\text { 前壁の骨欠損幅 } \\
\quad(\mathrm{mm})\end{array}$ & $11.0 \pm 6.1$ & $13.0 \pm 7.7$ & $5.5 \pm 5.2$ \\
\hline
\end{tabular}

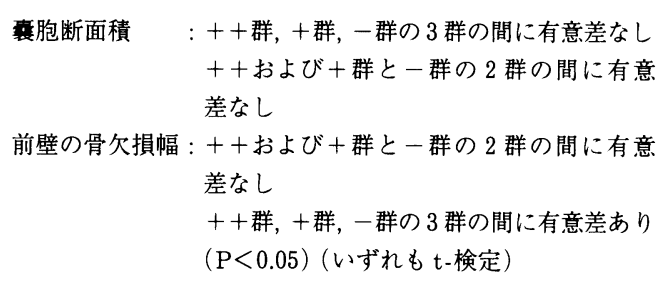

程度とも症状発現の有無とも有意な関連は認められな かった（表 9 ). 骨欠損の大きさについては, 症状の発 現により重要であることが示された前壁の骨欠損に注 目したところ，軸位 CT 像より計測した前壁の骨欠損 の最長幅は症状発現の有無とは危険率 $5 \%$ 以下で有意 な関連が認められ, 前壁の骨欠損の幅と症状の出現と は密接な関係があることが示された. 症状の程度との 間には有意な関連はなかった。
表10 蓑胞内への歯根突出と症状の程度との関係

\begin{tabular}{|c|c|c|c|c|}
\hline \multirow[b]{2}{*}{ 突出歯根 } & & 状 & 程 & \\
\hline & ++ & + & - & 計 \\
\hline あり & $13^{*}$ & 29 & 3 & 45 \\
\hline な L & 15 & 44 & 39 & 98 \\
\hline 計 & 28 & 73 & 42 & 143 \\
\hline
\end{tabular}

* 症例数を示す

++ 群, +群, 一群の 3 群の間に有意差あり $(\mathrm{P}<0.01)$

+十および+群と一群の 2 群の間に有意差あり

$(\mathrm{P}<0.01)\left(\right.$ いずれも $\chi^{2}$-検定 $)$

4 ) 囊胞と歯牙との位置的関係との関連

歯根の突出の有無は症状の程度との間には有意な関 連はなかったが, 症状発現の有無との間には危険率 1 \%以下で有意な関連が認められ, 歯根の突出がある場 合に症状が発現しやすいことが示された（表10）.

\section{7. 症状の種類に関連する因子について}

何らかの自・他覚的症状があり, 術前に CT 撮影を 行った101例について, 自・他覚的症状を煩部, 口腔内, 鼻, 眼症状に大別して, 症状の種類と関連する因子を 検討した。

上顎洞炎根治術時および本疾患発症時の年齢，上顎 洞炎根治術後の経過年数, 性別, 初発再発か, 囊胞 の形状, 囊胞や骨欠損の大きさなどの因子は症状の種 類との関連はなかった. 以下に, 症状の種類との関連 がみられた因子についての結果を示す。

1 ) 囊胞や骨欠損の位置との関連

囊胞の上下的位置と症状の種類との関連では, 下方 型では口腔内症状が, 上方型と全体型では頬部症状が 最も多かった（表11）。硬口蓋より下方に及ぶものとそ れ以外の型とに分類しても, 硬口蓋より下方に及ぶも のでは口腔内症状が, それ以外のものでは頓部症状が 最も多かった。鼻, 眼症状は頻度は少ないとはいえ， 上方型と全体型の場合に多かった．特に，眼症状を呈 した症例は囊胞が眼窩側に増大した症例であった。

骨欠損部位を考慮に入れた囊胞の前後的位置と症状 の種類との関連では, 前方型では煩部症状が, 全体型 では口腔内症状が最も多かった（表12）。全体型では， 㚘部, 口腔内症状よりは頻度は低いとはいえ，鼻症状 が高頻度にみられた. 特に, 鼻症状を呈した症例は囊 胞が鼻腔側に増大した症例であった。

2 ) 囊胞と歯牙との位置的関係との関連

襄胞内に歯根の突出がみられた症例では口腔内症状 が, 歯根の突出がみられない症例では煩部症状が最も 多かった（表13）。鼻, 眼症状は頻度は少ないとはいえ， 歯根の突出がみられない症例の方が多かった。 
表11 症状の種類と襄胞の位置（上下的）との関係

\begin{tabular}{|c|c|c|c|c|c|}
\hline \multirow[b]{2}{*}{ 位 置 } & \multicolumn{5}{|c|}{ 症 状 の 種 類 } \\
\hline & 煩部 & 口腔内 & 鼻 & 眼 & 計 \\
\hline 上方 型 & $21^{*}$ & 9 & 8 & 1 & 39 \\
\hline 下 方 型 & 21 & 51 & 2 & 0 & 74 \\
\hline 全 体 型 & 48 & 31 & 11 & 2 & 0 \\
\hline 計 & 90 & 91 & 21 & 3 & 205 \\
\hline $\begin{array}{l}\text { 硬口蓋より下方 } \\
\text { におぶもの }\end{array}$ & 51 & 81 & 6 & 1 & 139 \\
\hline それ以外 & 39 & 10 & 15 & 2 & 66 \\
\hline 計 & 90 & 91 & 21 & 3 & 205 \\
\hline
\end{tabular}

* 延べの症例数を示す

表12 症状の種類と襄胞の位置（前後的）との関係

\begin{tabular}{|c|c|c|c|c|c|c|c|}
\hline \multirow{2}{*}{\multicolumn{3}{|c|}{ 位＼cjkstart置 }} & \multicolumn{4}{|c|}{ 症 状 の 種 類 } & \multirow[b]{2}{*}{ 計 } \\
\hline & & & 㚘部 & 口腔内 & 鼻 & 眼 & \\
\hline 上 & 方 & 型 & $59 *$ & 47 & 4 & 2 & 112 \\
\hline 後 & 方 & 型 & 3 & 6 & 1 & 0 & 10 \\
\hline 全 & 体 & 型 & 27 & 38 & 16 & 1 & 82 \\
\hline \multirow[t]{2}{*}{ 閉 } & 鎖 & 型 & 1 & 0 & 0 & 0 & 1 \\
\hline & 計 & & 90 & 91 & 21 & 3 & 205 \\
\hline
\end{tabular}

* 延べの症例数を示す

表13 症状の種類と歯根突出との関係

\begin{tabular}{|c|c|c|c|c|c|}
\hline \multirow[b]{2}{*}{ 歯根の突出 } & \multicolumn{5}{|c|}{ 症 状 の 種 類 } \\
\hline & 煩部 & 口腔内 & 鼻 & 眼 & 計 \\
\hline あり & $36 *$ & 69 & 8 & 0 & 113 \\
\hline な し & 54 & 22 & 13 & 3 & 92 \\
\hline 計 & 90 & 91 & 21 & 3 & 205 \\
\hline
\end{tabular}

* 延べの症例数を示す

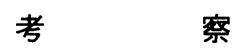

今回の症例における, 性別, 上顎洞炎根治術時ある いは本疾患発症時の年齢, 上顎洞炎根治術後の経過年 数, 症状, 囊胞の形状, 襄胞の位置, 囊胞と曾牙との位 置関係などの検討結果は,これまでの報告と比較して 明らかな差異はみられなかった。

性別では，女性よりも男性に多いという報告 2，4７） が多く, 男女比は $3: 1 \sim 1 ： 1$ の範囲である.今回 の結果でも男女比は1.68：1であり，その範囲内であっ た. 上顎洞炎根治術時年齢は, 金田 ${ }^{8}$ ), 前田 ${ }^{9}$ ), 竹井 ${ }^{10)}$
らの報告では10歳台〜 60歳台に及び，30歳台〜 40 歳台が最も多いとしている.今回の結果では10歳 台が最も多く，松岡ら 5 ) が報告しているように， 比較的若年期に上顎洞炎根治術を受けた場合に本 疾患を発症しやすいことがうかがわれた．当科の 初診時年齢もこれまでの報告にほぼ一致し，40歳 台に多くみられた.上顎洞炎根治術から本疾患発 症までの経過年数も平均25.5年で従来の報告に一 致していたが, 経過年数は 5 年から 57 年とかなり のばらつきがみられた。

主訴および自・他覚的症状としては, 田屍 ${ }^{11)}$, 田村 ${ }^{12)}$, 関谷 ${ }^{13)}$, 岸本ら ${ }^{14)}$ の報告と同様に煩部症 状が最も多かったが, 岸本ら ${ }^{14)}$ が多いと報告した 口腔症状もかなり多かった。手術側には左右差は なく, 症状の発現にも左右差はみられなかった。

輷胞の形状としては単胞性のものが多く，その 頻度も従来の報告15,16) とほほ同様であった. 虽胞 の上下的位置は, 宮沢 ${ }^{2)}$, 鶴田ら ${ }^{17)}$ の報告と同様 に上方型は少なかったが，下方型よりも全体型が 多かった点はそれらの報告と異なっていた．前後 的位置は前田ら ${ }^{9)}$ の報告とほほ同様に後方型が 少なく前方型, 全体型が多かった。囊胞内に歯根 の突出を認めた歯は第一大臼歯，第二小臼歯が多 く，これも従来の報告9) とほほ同様であった.

本襄胞の形状には多胞性のものと単胞性のもの があり，上顎洞炎根治術から本疾患発症までの経 過年数もかなりのばらつきがみられる。これらの 違いがある理由の 1 つとして, 本囊胞の発生機転 が1つではないことが考えられる，本襄胞の成因 について久保は貯留囊胞説と間隙囊胞説の 2 説を 発表したが1)，現在後者については否定的であ

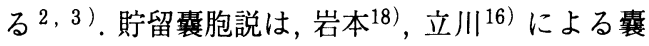
胞壁の組織学的検索, 朴19）による動物実験, 黑

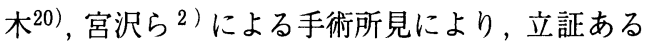
いは支持されている.また，赤池ら ${ }^{21)}$ の洞孤立説， 飯沼 $5^{3)}$, 毛利 ${ }^{22)}$ の閉鎖腔説も現在有力視され ている. 土田ら 23) はルーレット・トモグラムにて 上顎洞炎根治術後に経時的に再生上顎洞の変化を 検討し, 固有鼻腔と再生上顎洞との間の対孔形成 部が繰り返される上気道の炎症などで狭窄, 時に は閉塞を起こし，ついには襄胞を形成すると報告 している. 多胞性囊胞の成因についても, 再生上顎洞 内に生じたいくつかのくびれ部分が固有鼻腔と再生上 顎洞が閉塞するのと同様に閉塞するためとしている. 今回検討した 21 例の術後性上顎囊胞の再発症例の中で, 初回手術を当科で行ったものが7例含まれていた。こ れらの症例を検討してみると, その再発の原因は対孔 形成部の狭窄と思われ, 再発までの経過年数も 2 か月 から 6 年とかなり短かった. 浅野ら 24) も術後 5 年以上 の上顎洞の治癒過程について検討し, 早期に CT 上で 
軟組織陰影を認めることが多いと報告している。君塚 ら 25) は, 術後約 1 年後の再発症例の原因は度重なる感 染による開空部の閉鎖によるものとしているが，この ことより, 対孔形成部の閉塞によって生じた場合は発 症までの経過が短く, 貯留囊胞による場合は比較的経 過が長くなるものと考えられた。

本研究ではさらに, 症状の有無やその程度と関連す る因子を検討したところ, 囊胞の形状, 囊胞の位置, 歯牙との関係, 骨欠損の位置や大きさといった因子が 症状の発現の有無と有意な関連をもっていたが, 囊胞 自体の大きさは必ずしも症状の発現に関与していなかっ た。また, 症状の程度と関連があるのは囊胞の形状の みであり，他の因子は明らかな関連を示さなかった。

単胞性か多胞性かという囊胞の形状が症状発現の有 無とも症状の程度とも関連がある理由は不明である。 囊胞上皮の性状や囊胞の成因が関与しているものと推 察されるが, 今後の検討が必要である. 骨欠損の有無 やその大きさが症状の発現に関与している理由として は, 軟組織内では囊胞の拡大が容易で, その増大速度 も早く, 腫脹などの症状を呈しやすく, 感染する危険 性も高くなることが考えられる. 震胞の位置が低いほ ど症状が発現しやすい理由としては，おそらく歯牙と 近接することが多くなるからと考えられる. 囊胞と歯 根が近くなれば, 歯牙への神経や血管などを圧迫し障 害するであろうし, 感染を伴って種々の歯牙症状を呈 するものと思われる.あるいは逆に, 根尖病巣などが あれば, 囊胞内が感染して症状の発現につながること も考えられる。

症状の種類と関連する因子を検討したところ，豪胞 や骨欠損の位置, 囊胞と歯牙との関係との間に有意な 関連がみられた．豪胞が上方あるいは全体に位置する ものでは煩部症状が下方に位置するものでは口腔内症 状が多く出現しており，前壁に骨欠損があるものでは 煩部症状が, 前壁にも後壁にも骨欠損があるものでは 口腔内症状が多く出現していた。 また，囊胞内に歯根 が突出している場合には口腔内症状が高頻度に出現し ていた.さらに, 鼻, 眼症状は発現頻度は低いとはい え, 鼻症状は鼻腔側への, 眼症状は眼窩側への囊胞の 増大と密接に関連していた，以上のように，囊胞や骨 欠損の位置, 囊胞と歯牙との関係をみることにより, 出現する症状の種類もある程度予想できることが示さ れた。

本研究では囊胞内容液の性状や同定された菌種につ いても検討したが, 囊胞内容液の性状と同定された菌 種との明らかな関連はみられず，また，これらと症状 の程度や種類との間にも明らかな関連はなかった。こ れらの結果は手術を施行した症例だけから得られるの で, 今回は症状のない囊胞についての結果はほとんど なく, 症状発現の有無との関連については検索できな かった.おそらく, 症状発現には細菌感染が関与して
いると推察されるが, 今後検討を加える予定である.

術後性上顎囊胞では, 時に症状がない場合でも CT によって囊胞が認められることがあり，特に反対側に 症状があって手術を施行する際に，両側同時に手術を 行うべきか否かの判断にせまられる場合がある。また 手術を見合わせる場合にも，患者に病状を説明する場 合にはある程度予後を推定する必要がある。本研究に より, 囊胞の形状, 襄胞の位置, 骨欠損の位置や大き さ，歯牙との位置的関係などの所見は症状の発現と， また, 囊胞や骨欠損の位置, 歯牙との位置的関係は発 現する症状の種類と関連しており, 経過を推定できる 基準になりうることが示された.

\section{結語}

今回，当科で手術を施行した 169 症例の術後性上顎 襄胞を有する患者について, 手術までの経過, 症状, 襄胞の形状，囊胞や骨欠損の位置および大きさ，囊胞 と歯牙との位置的関係などを検討した．さらに，以下 の因子が症状の発現や症状の種類と関連していること が示された。

\section{1. 䡬胞の形状}

単胞性のものより多胞性のほうが症状の発現頻度は 高く, 症状の程度も強かった。

\section{2 . 囊胞の位置と大きさ}

囊胞の位置が低い場合には症状の発現頻度は高く， 特に口腔内症状が多かった。一方囊胞の位置が高い場 合には煩部症状が多かった。しかし，囊胞の大きさは 症状の発現との有意な関連はなかった。

3 . 骨欠損の位置と幅

前壁に骨欠損がある場合，さらにその幅が大きい場 合には, 症状の種類にかかわらず症状の発現頻度は高 く，その中でも煩部症状が多かった.

4. 歯根との位置的関係

囊胞内に歯根が突出する場合には症状の発現頻度は 高く, 特に口腔内症状が多かった.

本研究により, 囊胞の形状, 囊胞の位置, 骨欠損の 位置や大きさ, 歯牙との位置関係などの所見は症状の 発現あるいは症状の種類と密接に関連しており, 症状 のない囊胞の場合にその後の経過を推定し, 手術の適 応かどうかを判断する基準になりうることが示された.

本論文の要旨は1995年10月第40回日本口腔外科学会総 会 (東京)にて発表した。

\section{引用文 献}

1）久保猪之吉 : 上顎洞炎根治術後に現われたる煩 部囊腫. 大耳鼻会報 33: 896-897 1027.

2）宮沢正純, 白石豊彦, 他 : 術後性上顎囊胞の臨 
床的研究. 日口外誌 25: 1427-1432 1979.

3）飯沼寿孝: 術後性上顎襄腫の知見補遺.耳喉 44: 545-550 1972 .

4）上田隆志, 鶴田至宏, 他 : 当科における最近の 副鼻腔囊胞疾患. 耳鼻臨床 補37: 121-127 1990.

5）松岡寿子, 渡辺 啓, 北尾友幸：術後性上顎裹 胞の臨床統計的観察.耳鼻臨床 71: 1069-1075 1978.

6）栫 博幸, 青山 敬, 他 : 副鼻腔輬胞手術の臨 床統計. 耳鼻臨床 補59: 43-52 1992.

7）小川晃弘, 宇野欽哉, 小池聰之：副鼻腔囊胞 60 症例一原発性, 術後性の対比において一。聑喉 59: 1039-1044 1987.

8）金田宏和, 鶴田至宏, 他 : 慢性副鼻腔炎根治術 施行症例の臨床統計.耳鼻臨床 補37: 114-120 1990.

9）前田好正, 広田重水, 他：術後性上䪽囊胞の臨 床 ·組織学的検討. 口科誌 36: 25-31 1987.

10) 竹井 隆 : 慢性副鼻腔炎上顎洞粘膜の病理組織 学的研究.耳鼻臨床 13: 229-251 1969.

11）田屍佐賀雄：我が教室に於ける術後煩部囊腫の 統計的観察 (抄).日耳鼻 57: 1071054 .

12）田村外男: 術後性煩部虽腫の研究. 日耳鼻 63: 319-332 1960 .

13）関谷 透, 松本圭晿, 他：術後性煩部囊腫につ いて一症例とその統計的観察一. 耳喉 37: 3513551965 .
14）岸本宏史, 斉藤寿章, 他 : 術後性上顎震胞の臨 床的研究. 日口外誌 36: 547-552 1990.

15）柳田昌宏, 山下敏夫, 他 : 術後性上顎囊胞の MRI. 耳鼻臨床 85: 61-68 1992.

16）立川 潤 : 術後性上顎囊胞に関する臨床病理学 的研究. 歯科学報 75: 1117-1142 1975.

17）鶴田至宏, 松永 喬, 他: 術後性上顎囊胞の $\mathrm{X}$ 線学的分類による臨床統計的観察. 耳鼻臨床 補 37: 128-133 1990.

18）岩本彦之丞：術後性煩部襄腫の臨床的ならびに 組織学的観察. 臨床と研究 24: 220-224 1947.

19）朴 泳敦: 術後性煩部躟腫形成の実験的研究. 福岡医誌 33: 1 -33 1940 .

20）黑木康雄 : 副鼻腔炎の臨床的研究. 耳鼻臨 53 (増刊号 1 ) : 1128-1135 1960.

21）赤池清美, 渡辺一夫, 他 : 慢性副鼻腔炎の再手 術所見. 耳喉 36: 821-824 1964.

22) 毛利 学, 西尾正寿, 他: 術後性上顎囊腫の問 題点. 日耳鼻 80: 327-333 1977.

23）土田武正, 新垣裕弘, 飯塚弘志: 手術後性煩囊 腫の成因について. 耳喉 44: 29-32 1972.

24）浅野 智, 吉澤信夫 : 術後性上顎囊胞に対する 手術後の長期経過例の評価. 口科誌 44: 676-683 1995.

25）君塚 哲, 越後成志, 他 : 術後性上顎囊胞の臨 床病理学的考察. 日口外誌 41: 699-704 1995. 